\title{
14-3-3 Lambda Protein Affects Anthocyanin Production in Arabidopsis thaliana during Drought Stress
}

\author{
Fizal Nabbie ${ }^{1}$, Jordan Smith ${ }^{1}$, Serhiy Hnatyshyn ${ }^{3}$, Bethanne Warrack ${ }^{3}$, Huidong $\mathrm{Gu}^{4}$, Daniel Merenich ${ }^{1}$, \\ Kenneth Myers ${ }^{1}$ \& Bela Peethambaran ${ }^{1,2}$ \\ ${ }^{1}$ Department of Biological Sciences, University of the Sciences in Philadelphia, Philadelphia, PA, USA \\ ${ }^{2}$ Department of Chemistry \& Biochemistry, University of the Sciences in Philadelphia, Philadelphia, PA, USA \\ ${ }^{3}$ Bristol Myers Squibb, Pharmaceutical Candidate Optimization, Princeton, NJ, USA \\ ${ }^{4}$ Bristol Myers Squibb, Bioanalytical Sciences, Princeton, NJ, USA \\ Correspondence: Bela Peethambaran, Department of Chemistry \& Biochemistry, Department of Biological \\ Sciences, University of the Sciences in Philadelphia, 600 South $43^{\text {rd }}$ St. Philadelphia, PA 19104, USA. Tel: \\ 1-215-596-8923. Fax: 1-215-596-8710. E-mail: b.peethambaran@usciences.edu
}

Received: April 6, 2017

doi:10.5539/jas.v9n7p22
Accepted: May 9, 2017 Online Published: June 15, 2017

URL: https://doi.org/10.5539/jas.v9n7p22

\begin{abstract}
Plants evolve to adapt to environmental stresses, including changes at the genetic and molecular levels. For bioengineers to utilize genetic manipulation to build tolerance into crops, a better understanding of the

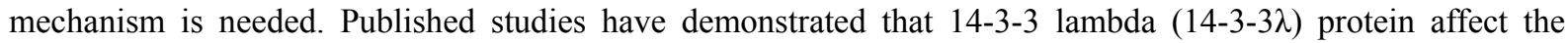
phenylpropanoid $(\mathrm{Pp})$ biosynthetic pathway and alters production of flavonoids and downstream compounds of importance for stress tolerance. The 14-3-3 family of proteins binds to many different client proteins and serves

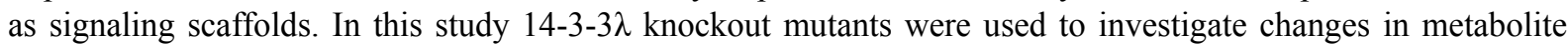
accumulation in the downstream Pp pathway. Amongst them are anthocyanins which are important antioxidants involved in a variety of plant functions including stress response. Investigating how drought stress influenced anthocyanin production identified nodes in the Pp pathway affected by 14-3-3 $\lambda$. A metabolomics analysis employing high resolution mass spectrometry (HRMS) and metabolomics software was used to identify metabolites in 14-3-3 knockout which changed relative to wild-type A. thaliana (Columbia-0) during drought stress. The metabolites Cy-3-p-coumaurolysinapoylsophoroside-5-diglucoside, 3-caffeoylferuloylsophoroside5-succinoylglucoside, 3-caffeoylferuloylsophoroside-5-malonyldiglucoside, 3-feruloylsophoroside-5-succinoyl glucoside, petunidin-3,5-O-diglucoside and malvidin-3-O-p-coumarylmonoglucoside show significant differences in their profiles ranging from 18- to $>500$-fold between the Col-0 and 14-3-3 $\lambda$ knockout in wet and dry groups. The findings suggest that 14-3-3 interacts along the CHS, and CHI nodes, which in turn regulate the downstream production of specific anthocyanins. The interaction of 14-3-3 $\lambda$ with CHS was confirmed using co-immunoprecipitation and co-localization studies. This study supports the hypothesis that manipulation of gene expression of 14-3-3 $\lambda$ can lead to development of drought tolerance in plants.
\end{abstract}

Keywords: anthocyanin biosynthesis, Arabidopsis thaliana, drought stress, phenylpropanoid pathway, 14-3-3 $\lambda$

\section{Introduction}

In A. thaliana there are several isoforms of 14-3-3 proteins (DeLille, Sehnke, \& Ferl, 2001; Ferl, 1996). The 14-3-3 proteins are a highly conserved family of proteins in eukaryotic organisms and have been studied thoroughly in various plant models including A. thaliana (DeLille et al., 2001; Lukaszewicz, Matysiak-Kata, Aksamit, Oszmianski, \& Szopa, 2002; Muslin \& Xing, 2000; Paul, Denison, Schultz, Zupanska, \& Ferl, 2012). First purified from bovine brain(Moore, 1967), the 14-3-3 proteins were originally thought to be associated with neural tissue (Ichimura et al., 1988), but later found to be highly conserved among other eukaryotes including plants (Ferl, 1996; Li et al., 2015; Rosenquist, Sehnke, Ferl, Sommarin, \& Larsson, 2000). The 14-3-3 proteins are capable of dimerizing and binding to the phosphorylated motif of multiple partners at the same time, bringing proteins together. This allows 14-3-3 to play critical roles in the signaling pathways through interactions with various binding partners (Aitken, 1996; Roberts, 2003). The binding sites which are in the C-terminal regions have little homology among the isoforms and this factor plays a role in their varied cellular localizations (Berg, 
Holzmann, \& Riess, 2003; Bihn, Paul, Wang, Erdos, \& Ferl, 1997; Lapointe, Luckevich, Cloutier, \& Séguin, 2001; Martin, Rostas, Patel, \& Aitken, 1994) and its functions (Bunney, van Walraven, \& de Boer, 2001; Kumar, Muthamilarasan, Bonthala, Roy, \& Prasad, 2015). It has been demonstrated that knockout of 14-3-3 in potato plant can result in a major decrease in antioxidant capacity highlighting 14-3-3 importance in the Pp pathway (Lukaszewicz et al., 2002). The 14-3-3 proteins have also been shown to affect a variety of cellular processes in plants in response to environmental stress factors such as dehydration, insect attack and UV (Jahn et al., 1997; Li et al., 2015; Roberts, Salinas, \& Collinge, 2002).

From previously published studies, it was suggested that 14-3-3 proteins affect production of anthocyanins which are a family of molecules involved in a variety of functions including defense (Dixon \& Steele, 1999; He et al., 2010; Holton \& Cornish, 1995). As one example anthocyanin loss of function lines of $A$. thaliana grown under high light conditions, showed no significant growth difference compared to controls, suggesting that anthocyanins major role in the Pp pathway may be focused on other functions such as defense and stress response (Misyura, Colasanti, \& Rothstein, 2012). Numerous studies have been conducted on the anthocyanin biosynthesis in $A$. thaliana, but the role of 14-3-3 proteins on anthocyanin production remains unresolved and specific nodes of interaction in the anthocyanin pathway by 14-3-3 proteins has not been fully elucidated.

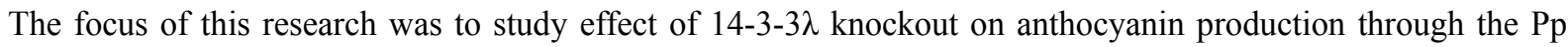
pathway in Arabidopsis thaliana, under drought stress (dry) conditions. Published research has identified the 14-3-3 $\lambda$ mutant as having greater sensitivity to dry conditions (Peethambaran, Chi Li, Dzugan, Xiang, \&

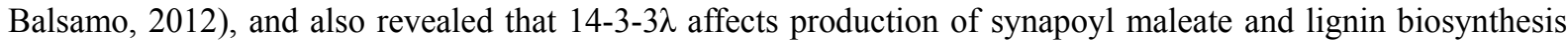
under dry conditions (Lindberg et al., 2014). These findings indicate that 14-3-3 proteins are interacting along

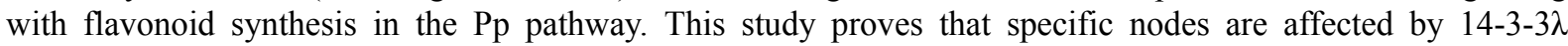
proteins in production of anthocyanins. A reverse genetics approach was applied to screen anthocyanin metabolites under dry and well hydrated (wet) conditions using A. thaliana 14-3-3 $\lambda$ homozygous TDNA

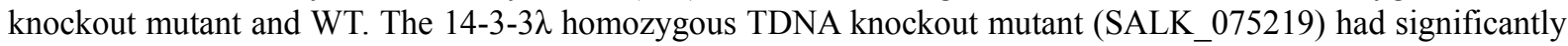
different amounts of total flavonoid, phenolics and antioxidants compared to Columbia-0 (WT) under dry conditions. This provided the rationale for investigating differentially regulated anthocyanins in 14-3-3 $\lambda$

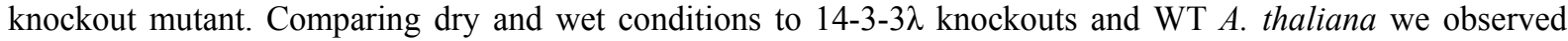
significant increases in the metabolites listed in Table 1, for WT, with smaller changes in the 14-3-3 $\lambda$ knockout

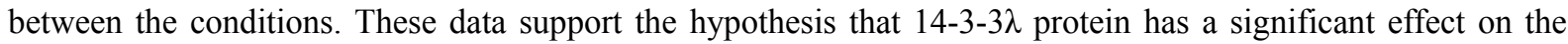
Cyanidin and Delphinidin nodes of the Kegg anthocyanin biosynthetic pathway. Moving further upstream of anthocyanins, in the Pp pathway these are metabolites produced by the action of Chalcone Synthase (CHS) and Chalcone Isomerase (CHI) nodes. The CHS gene has been shown to have an elevated transcription rate under environmental and pathogenic stress conditions resulting in accumulation of various flavonoids and anthocyanins (Feinbaum \& Ausubel, 1988; Li \& Strid, 2005). CHI mutants have been shown to have lower levels of flavonoids and high sensitivity to UV-B damage. When the CHS and CHI knockouts were drought stressed, lower expression of 14-3-3 was observed, suggesting that CHS and CHI interact with 14-3-3 during dry conditions.

\section{Materials and Methods}

\subsection{Plant Growth Conditions, Drought Stressing and Sampling}

Wild-type (Columbia-0), 14-3-3 T-DNA mutant Lambda (SALK_075219), CHS T-DNA mutant (SALK_077592) and CHI T-DNA mutant (SALK_ 034145) were purchased from Arabidopsis Biological Resource Center (ABRC, Ohio State University). Seeds were grown in a Sunshine Mix soil (Sun Gro Horticulture, Quincy, MI) and hydrated with Scotts peters professional water soluble fertilizer 20-20-20 (Scotts, Marysville, OH) as previously described (Lindberg et al., 2014). Genotypting of these knockout lines were conducted using polymerase chain reaction and western blot for the 14-3-3 T-DNA mutant Lambda (SALK_075219). Drought treatment was carried out on 5 week old plants, half of the plants were watered normally and the other half was not watered, soil moisture was monitored daily and leaf mass harvested from all plants when the drought treated soil moisture level reached $\sim 30 \%$, at which point wilting of the leaves was observed. Harvested leaves were immediately frozen in liquid nitrogen and freeze dried (LabConco Corporation, Kansas City, MO). The dried leaf samples were stored at $-80^{\circ} \mathrm{C}$ until extraction.

\subsection{Metabolite Extraction and Isolation}

Metabolites were extracted using a modification of the method described by (Lindberg et al., 2014). Briefly, frozen tissue was ground with a mortar and pestle, then suspended in extraction solvent (Methanol:Acetone; 1:1 $\mathrm{v} / \mathrm{v})$, followed by addition of $1 \mu \mathrm{g}$ of apeginin $\left(10 \mu \mathrm{g} \mathrm{mL}^{-1}\right)$ as an internal standard. The supernatant was 
transferred to a BD Falcon tube (ThermoFisher Scientific, Waltham, MA). The pellet was extracted two more times with extraction solvent and dried using a Savant SpeedVac centrifugal evaporator (Savant Instruments Inc., Farmingdale, NY). Chlorophyll was precipitated by addition of acetone then water at a 70:40 v/v ratio and centrifugation at $13,000 \times \mathrm{g}$. The supernatant was dried using the Savant SpeedVac, samples were reconstituted in a 10:90 ratio of methanol $/ 0.1 \%$ formic acid in water and analyzed by LC-MS.

\subsection{LC-MS Conditions}

Samples were analyzed by Liquid Chromatography/Mass Spectrometry using an Accela UHPLC interfaced to an Exactive Plus ion trap mass spectrometer with a HESI source (ThermoFisher Scientific, San Jose, CA). Chromatographic separations were achieved employing a $2.1 \times 150 \mathrm{~mm}, 5 \mu \mathrm{m}$, Imtakt Flavonoid RP18 column (Portland, OR) with gradient elution at $0.6 \mathrm{~mL} / \mathrm{min}$. The column temperature was maintained at $65{ }^{\circ} \mathrm{C}$. Mobile phase A was water with $0.1 \%$ formic acid and mobile phase B was $98: 2$ acetonitrile:water with $0.1 \%$ formic acid. Mobile phase A was held at $100 \%$ for 0.5 min and then a three step linear gradient was formed from $0 \%$ to $20 \%$ mobile phase B over $5.5 \mathrm{~min}$, to $60 \%$ mobile phase B in $2 \mathrm{~min}$ and then to $95 \%$ phase B in $4 \mathrm{~min}$. The final composition was held for $1 \mathrm{~min}$ before returning to the initial conditions. Positive and negative electrospray ionization (ESI) data were acquired (separate injections) from $\mathrm{m} / \mathrm{z} 200$ to $\mathrm{m} / \mathrm{z} 1200$ with a mass accuracy within $5 \mathrm{ppm}$ at 35000 resolutions. A single $10 \mu \mathrm{L}$ injection was used for each ionization mode. Instrumental settings follow: maximum injection time $10 \mathrm{msec}$, capillary temperature $320^{\circ} \mathrm{C}$; tube lens voltage $175 \mathrm{~V}$; ESI spray voltage $4.3 \mathrm{kV}$ for positive ion mode, $3.6 \mathrm{kV}$ for negative ion mode; sheath gas 2 arbitrary units (arbs).

\subsection{Total Flavonoid, Phenolic, Antioxidant and Free Radical Scavenging Analysis}

Analysis was performed using modifications of the methods described by Kiranmai et al., and Mahboubi et al., (Kiranmai et al., 2011; Mahboubi, Kazempour, \& Boland Nazar, 2013), the response from each assay was calculated using $4 \mathrm{PL}$ curve fitting and expressed as $\mu \mathrm{g} \mathrm{mL}^{-1}$.

\subsubsection{Total Phenolic}

Total phenolic contents in the sample extracts was determined using the Folin-Ciocalteu's reagent (Folin \& Denis, 1912) and the method described by Mahboubi et al. We use $25 \mu \mathrm{L}$ aliquot of each sample extract and diluted calibrator solution (Gallic acid 15.6 to $1000 \mu \mathrm{g} \mathrm{mL}^{-1}$ in methanol) was mixed with $0.125 \mathrm{~mL}$ of Folin-Ciocalteu's reagent (10\%). After approximately 5 minute, $0.1 \mathrm{~mL}$ of $7.5 \%$ (w/v) sodium carbonate solution was added and mixed. That was followed by incubation for 1 hour and measure absorbance at $765 \mathrm{~nm}$.

\subsubsection{Total Flavonoid}

For total flavonoid contents we use a $25 \mu \mathrm{L}$ aliquot of each sample extract and diluted calibrator solution (Quercetin 15.6 to $1000 \mu \mathrm{g} \mathrm{mL}^{-1}$ in methanol) and mix with $75 \mu \mathrm{L}$ of ethanol (95\%), $0.5 \mu \mathrm{L}$ of aluminum chloride (10\%), $0.5 \mu \mathrm{L}$ potassium acetate $(1 \mathrm{M})$ and $140 \mu \mathrm{L}$ deionized water. That was followed by incubation at RT for 30 minutes and measure absorbance at $415 \mathrm{~nm}$.

\subsubsection{Total Antioxidant}

For total antioxidant activity was determined using the method described by Kiranmai et al., we use $100 \mu \mathrm{L}$ of each sample and diluted calibrator solution (Ascorbic acid 78 to $5000 \mu \mathrm{g} \mathrm{mL}^{-1}$ in methanol) and mix separately with $1.0 \mathrm{~mL}$ of a mixture of $(0.6 \mathrm{M}$ Sulfuric Acid $/ 28 \mathrm{mM}$ Sodium phosphate $/ 4 \mathrm{mM}$ Ammonium Molybdate). That was followed by incubation at $95{ }^{\circ} \mathrm{C}$ for 90 minutes, measure absorbance of the reaction mixture at $695 \mathrm{~nm}$.

\subsection{Protein Extraction, Quantification and Western Blot}

Protein extraction was carried out on freshly collected 0.1 gram plant leaf weight, frozen in Liquid Nitrogen and maintained frozen while samples were pulverized to a fine powder and mixed Laemmli buffer and boil at $95{ }^{\circ} \mathrm{C}$ for $10 \mathrm{~min}$. Centrifugate at $1000 \times \mathrm{g}$ for 5 minutes at $4{ }^{\circ} \mathrm{C}$.

\subsubsection{Protein Quantitation}

Protein was quantitated with a Thermo Scientific Pierce $660 \mathrm{~nm}$ Protein Assay kit (cat \#22662), in a ready-to-use format (Thermo Fisher Scientific, Waltham, MA). A $10 \mu \mathrm{L}$ aliquot of the kit pre-made Albumin standard solutions ranging from 0.125 to $2000 \mu \mathrm{g} \mathrm{mL}^{-1}$ and $10 \mu \mathrm{L}$ aliquots of the unknown protein samples extracts were added to wells in a clear flat bottom 96 well plate. An aliquot of $150 \mu \mathrm{L}$ of the kit developing reagent mixture was placed in the well of the microtiter plate containing samples and the plate incubate for $1 \mathrm{~min}$ at room temperature, then read at $660 \mathrm{~nm}$ on a Spectramax 386 plus plate reader (Molecular Devices, Sunnyvale, CA). Protein concentration was calculated using a linear curve fit in Softmax Pro ver 5.0 (Molecular Devices, Sunnyvale, CA) and unknown sample concentration read of the calibration curve. 


\subsubsection{Western Blot}

For the gel electrophoresis the Bio Rad Mini Protean TGX precast gel was used 4-15\% (Bio Rad, Raleigh, NC). $20 \mu \mathrm{g}$ of protein was mixed with $1 \mu \mathrm{L}$ of Bromophenol blue and volume completed to $15 \mu \mathrm{L}$ of with Laemmli buffer containing $\beta$-mercaptoethanol. Running buffer was $1 \mathrm{X}$ Tris-HCL-Glycine at $120 \mathrm{~V}$ for $60 \mathrm{~min}$. Blot with $1 \mathrm{X}$ transfer buffer Tris HCL-Glycine with $10 \%$ methanol at $70 \mathrm{~V}$ for $60 \mathrm{~min}$. Blocked with $5 \%$ non-fat milk in 1x TBST $1 \mathrm{hr}$ at RT. Incubated with the Santa Cruz anti-14-3-3 rabbit polyclonal antibody as a primary antibody (Santa Cruz Biotechnology Inc, Dallas, TX), 1:1000 dilution in 1x TBST with 5\% non-fat milk overnight at $4{ }^{\circ} \mathrm{C}$. Incubate blot in cell signaling HRP-anti-rabbit antibody (Cell Signaling Technology, Danvers, MA) as the secondary antibody at 1:10 000 dilution in $1 \mathrm{x}$ TBST with $5 \%$ non-fat milk $1 \mathrm{hr}$ at RT. Mix Thermo Scientific chemi substrate solutions in a 1:1 v/v ratio and apply to blot, incubate for $1 \mathrm{~min}$ and Image blot.

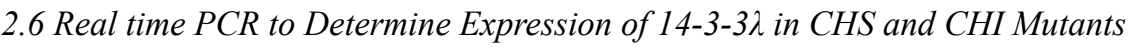

The RNA was isolated using Trizol methods (Chomczynski \& Sacchi, 1987), $0.1 \mathrm{gm}$ of tissue was flash frozen in liquid nitrogen and grounded into fine powder, $0.5 \mathrm{~mL}$ of Trizol added. After thawing, the mixture was transferred to an Eppendorf tube and centrifuged at 13,000 RCF for 5 minutes, add $0.2 \mathrm{ml}$ of chloroform and vortex briefly and incubate at room temperature for 10 minutes before centrifuging at $13,000 \mathrm{RCF}$. The top layer was moved into a new tube and $0.25 \mathrm{ml}$ of RNA precipitation solution $(0.8 \mathrm{M}$ Sodium citrate $/ 1.2 \mathrm{M} \mathrm{NaCl})$ and $0.25 \mathrm{ml}$ of isopropanol added, centrifugate at 13,000 RCF. The RNA pellet washed twice with $75 \%$ ethanol before air drying. RNA pellets dissolved in RNAse free water. The RNA was converted to cDNA using a

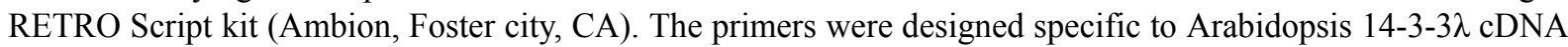

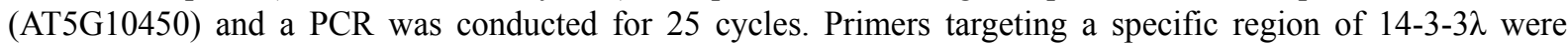
amplified using the forward primer 'TGCTGGAGCGAGTGAGTCTA' and reverse primer 'AGCCTGTTT GGCCATGTTAC'. An actin primer for gene ACT2 (AT3G18780) 'TCCAGTGTTGTTGGTAG GCCA' and TCTCAGCACCAATCGTGATGAC' was run at the same time to control for loading differences.

\subsection{Protein Immuno Precipitation and Co-Immuno Precipitation with Magnetic Beads}

Immuno precipitation (IP) of 14-3-3 and co-IP of binding partners was carried out with a Thermo IP/co-IP magnetic bead kit, catalog \#88805 (Waltham, MA) as described in the kit method. Briefly an antibody specific to 14-3-3 $\lambda$ was conjugated to the magnetic beads then crosslinked to permanently bind the antibody to the beads. The beads were exposed to $0.5 \mathrm{~mL}$ of protein extracts from wild type and $\mathrm{KO}$ plants for 1 hour at room temperature (RT) with gentle shaking to keep beads suspended. The captured protein along with binding partners was eluted with $100 \mu \mathrm{L}$ the low $\mathrm{pH}$ elution solution and 5 minutes of incubation at RT with gentle shaking. The eluate solution was transferred to a clean tube and neutralized with $10 \mu \mathrm{L}$ of neutralizing buffer as described in the kit manual. A $50 \mu \mathrm{L}$ aliquot of the eluate was diluted with $100 \mu \mathrm{L} 0.5 \mathrm{M}$ bicarbonate buffer digested with 50 $\mu \mathrm{L}$ of $1 \mathrm{mg} \mathrm{mL}^{-1}$ trypsin and $37^{\circ} \mathrm{C}$ overnight, then analyzed by LC-MS.

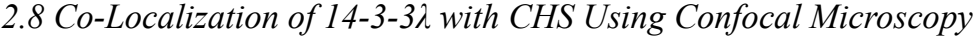

Microscopic imaging was performed on a spinning disk (Yokagawa CSU-X1; Andor Technology) confocal microscope using a 60x 1.4 NA oil immersion objective lens on a TiE microscope equipped with Perfect Focus System (Nikon) equipped with an electronic shutter (Sutter Instrument) for transmitted illumination, a linear encoded X and Y, motorized stage (ASI Technologies), and a multi-bandpass dichromatic mirror (Semrock) and bandpass filters (Chroma Technology Corp.) in an electronic filter wheel for selection of BFP, GFP, or RFP emission. 405-, 488-, and 561-nm laser illumination was provided by a high-powered ( $20 \mathrm{~mW} 405-\mathrm{nm}$; $50 \mathrm{~mW}$ 488- and 561-nm) monolithic laser combiner module (MLC 400B; Agilent Technologies) that were shuttered with electronic shutters and directed to a fiber-coupled output port with an Acousto optic tunable filter and to the confocal scan-head via a single mode polarization-maintaining fiber coupled delivery system (Agilent Technologies). The exposure times for the images were 500 milliseconds for 405 and $488 \mathrm{~nm}$ and $600 \mathrm{~ms}$ for 561 $\mathrm{nm}$. The primary antibody for 14-3-3 $\lambda$ was anti-mouse kindly gifted by Dr. Robert Ferl, University of Florida. A final dilution of 1:20 was followed according to the protocol of Pasternak et al. (2015). The secondary antibody for 14-3-3 $\lambda$ was tagged with Cy5 and a final dilution of 1:500 was used. The primary antibody used to probe chalcone synthase was from Agrisera (AS 12 2615). The secondary antibody for chalcone synthase was tagged with Cy3. Primary and secondary dilutions were 1:20 and 1:500 respectively (Pasternak et al., 2015).

\subsection{Statistical Analysis}

For total Flavonoid, Phenolic, Antioxidant and Free radical scavenging capacity, the differences between drought-treated versus untreated plants were analyzed with a paired t-test, in Microsoft Excel. Metabolite profiling analyses were carried out with MetaboAnalyst. Data was first transformed by log normalization and 
analyzed using t-test statistics in Microsoft Excel. P values obtained from the t-test were used to conclude significance $(\alpha=0.05)$.

\section{Results \& Discussion}

Analyses of total flavonoids, total phenolic, total antioxidant and free radical scavenging capacity in 14-3-3 $\lambda$ between wet and dry conditions, suggest a differential response in the Pp pathway regulating these molecules (Figure 1). The Col-0 wild-type showed no significant changes in total flavonoids and antioxidants, between wet and dry conditions; however, significant change in total phenolic was observed. In the 14-3-3 knockout, significant differences were observed for total flavonoids, phenolics, and antioxidants, demonstrating that 14-3-3 $\lambda$ knockout affect the flavonoid branch of the Pp pathway.

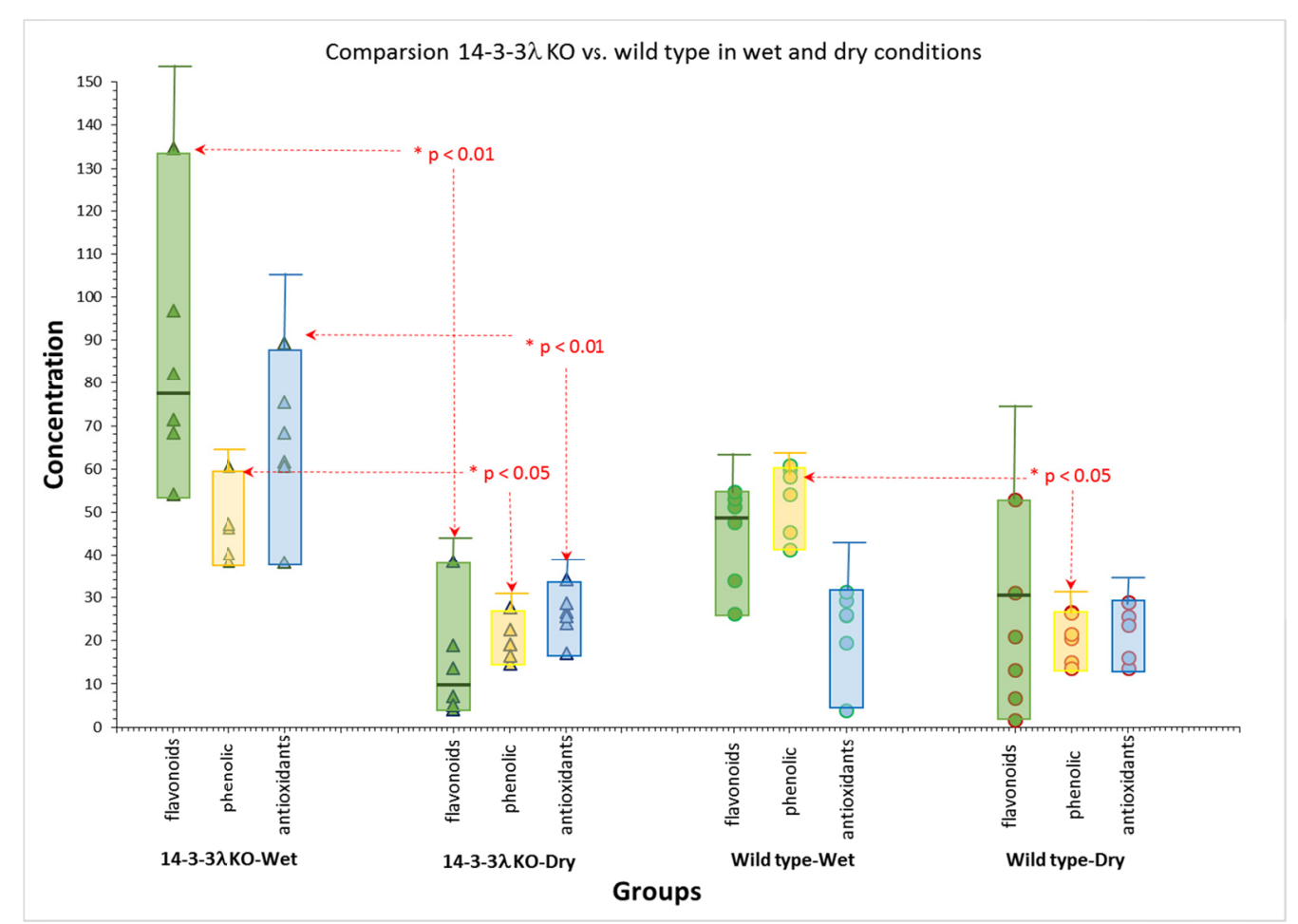

Figure 1. Spectrophotometric analysis of total Flavonoid, total Phenolic and total Antioxidant in A. thaliana

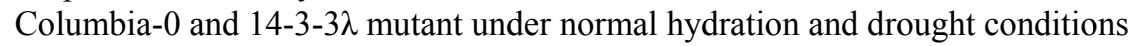

Metabolomics profiling is a well-accepted methodology for analysis of large numbers of metabolites and MetaboAnalyst has demonstrated utility in metabolite profiling (Xia, Sinelnikov, Han, \& Wishart, 2015).

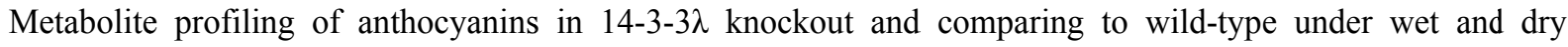
conditions by high resolution accurate mass Mass Spectrometry, representative chromatography (Figure 2) shows good peak resolution of the metabolite peaks across the run, a necessity for reliable metabolite profiling. 


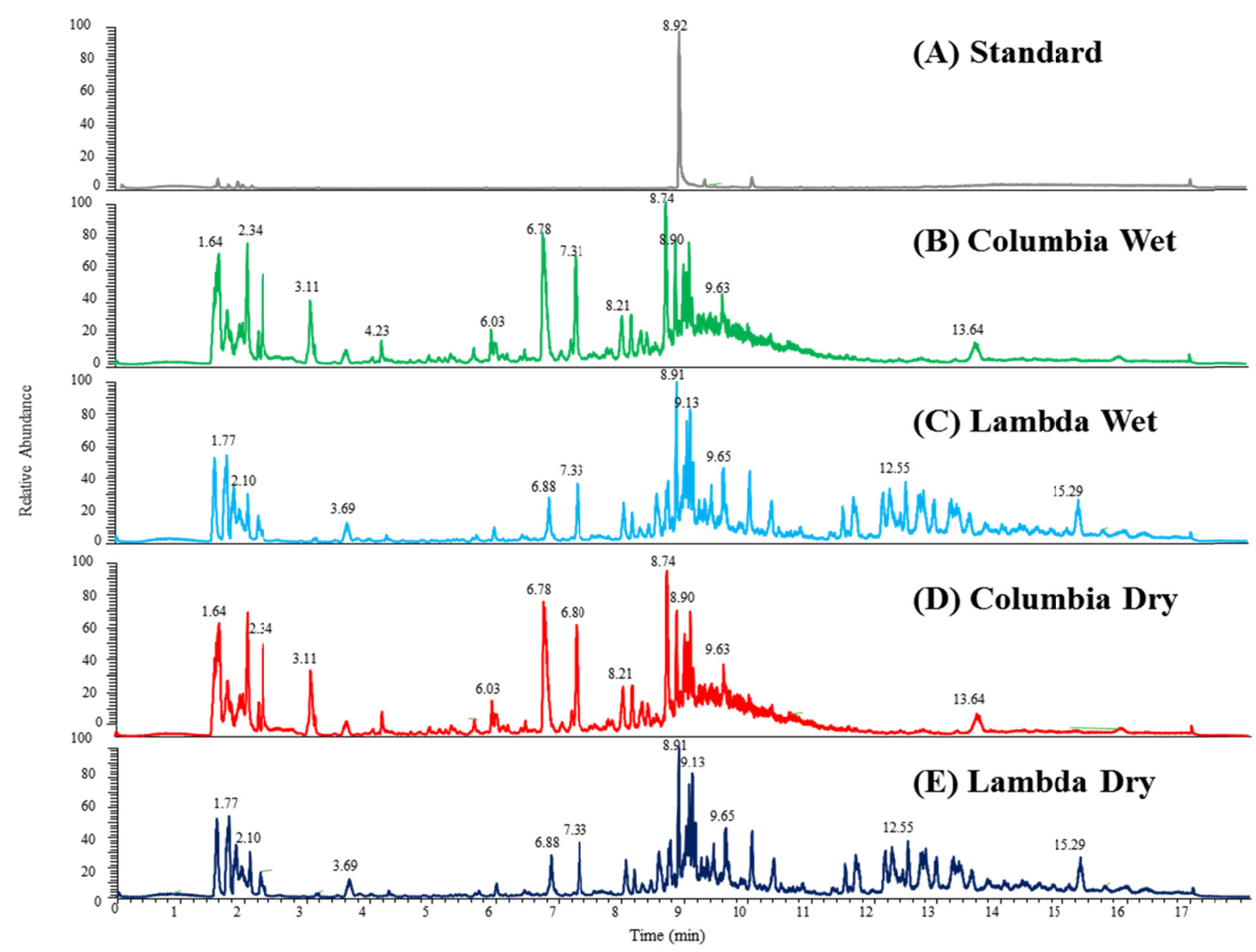

Figure 2. LC/MS total ion chromatograms for calibration standard and A. thaliana extracts, depicting typical separation of metabolites in the extracts. Calibration standard Kaempferitrin $32 \mu \mathrm{g} \mathrm{mL} \mathrm{m}^{-1}$ (A), Columbia-0 extract

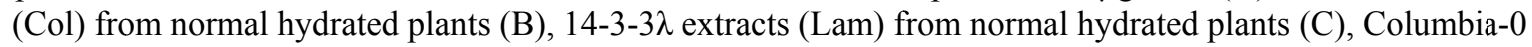

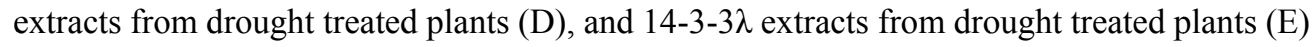

Principal Component Analysis (PCA) of all metabolites (Figure 3) shows that $45.2 \%$ of all variance in the analysis is accounted for in the model, providing confidence in the metabolite profiling data (Xia et al., 2015). 


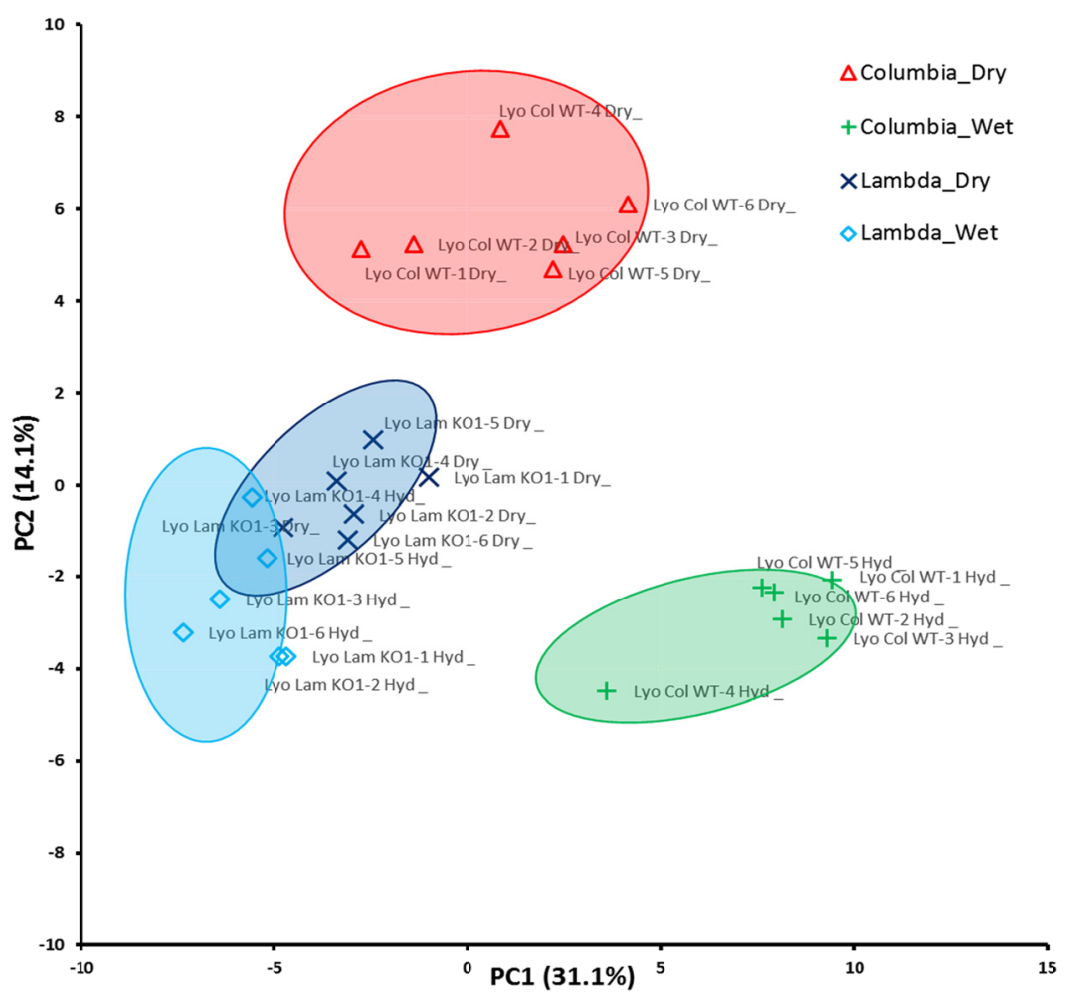

Figure 3. PCA analysis comparing wet and dry groups showing that $45.2 \%$ of the variance is accounted for in the model

Using a metabolomics approach several anthocyanin metabolites were identified as showing significant differences between the wet and dry groups (Table 1). 
Table 1. Summary of LC/MS metabolite profiling for normal hydration and drought treated wild-type

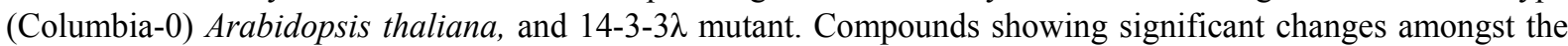
group are shown. Positive ionization mode LC/MS data (top frame, panel 1 and 2). Negative ionization LC/MS data (bottom frame, panel 3 and 4)

\begin{tabular}{|c|c|c|c|c|c|}
\hline \multirow{3}{*}{$\begin{array}{l}\text { Panel } 1 \\
\text { Metabolite Name }\end{array}$} & \multirow{3}{*}{ IonMZ } & \multirow{2}{*}{\multicolumn{2}{|c|}{$\begin{array}{c}\text { Wild Type Wet vs Dry } \\
\text { Col_Wet/Col_Dry }\end{array}$}} & \multirow{2}{*}{\multicolumn{2}{|c|}{$\frac{\text { Knockout Wet vs Dry }}{\text { Lam_Wet/Lam_Dry }}$}} \\
\hline & & & & & \\
\hline & & Fold Change & P Value & Fold Change & P Value \\
\hline 3-p-coumaroylsinapoylsophoroside-5-diglucoside & 644.1847 & 1.5 & $1.22 \mathrm{E}-01$ & -5.0 & 4.79E-03 \\
\hline 3-caffeoylferuloylsophoroside-5-succinoylglucoside & 604.1428 & 18.6 & $3.21 \mathrm{E}-03$ & 0.0 & $3.41 \mathrm{E}-01$ \\
\hline 3-caffeoylferuloylsophoroside-5-malonyldiglucoside & 678.1614 & 18.1 & $4.59 \mathrm{E}-03$ & -1.7 & $5.08 \mathrm{E}-01$ \\
\hline \multicolumn{2}{|l|}{ Panel 2} & \multicolumn{2}{|c|}{ Wet Wild Type vs Knockout } & \multicolumn{2}{|c|}{ Dry Wild Type vs Knockout } \\
\hline \multirow{2}{*}{ Metabolite Name } & \multirow{2}{*}{ IonMZ } & \multicolumn{2}{|c|}{ Col_Wet/Lam_Wet } & \multicolumn{2}{|c|}{ Col_Dry/Lam_Dry } \\
\hline & & Fold Change & P Value & Fold Change & P Value \\
\hline 3-p-coumaroylsinapoylsophoroside-5-diglucoside & 644.1847 & $>500$ & $3.72 \mathrm{E}-04$ & 65.9 & $6.34 \mathrm{E}-07$ \\
\hline 3-caffeoylferuloylsophoroside-5-succinoylglucoside & 604.1428 & $>500$ & $2.04 \mathrm{E}-03$ & 128.9 & $2.41 \mathrm{E}-01$ \\
\hline 3-caffeoylferuloylsophoroside-5-malonyldiglucoside & 678.1614 & 70.8 & $3.50 \mathrm{E}-03$ & 2.3 & $1.50 \mathrm{E}-01$ \\
\hline \multicolumn{2}{|l|}{ Panel 3} & \multicolumn{2}{|c|}{ Wild Type Wet vs Dry } & \multicolumn{2}{|c|}{ Knockout Wet vs Dry } \\
\hline \multirow{2}{*}{ Metabolite Name } & \multirow{2}{*}{ IonMZ } & \multicolumn{2}{|c|}{ Col_Wet/Col_Dry } & \multicolumn{2}{|c|}{ Lam_Wet/Lam_Dry } \\
\hline & & Fold Change & P Value & Fold Change & P Value \\
\hline Peonidin-3-O-monoglucoside & 461.1089 & 13.9 & $1.10 \mathrm{E}-03$ & -1.7 & $2.64 \mathrm{E}-02$ \\
\hline Cyanidin-3,5-O-diglucoside & 609.1465 & 1.4 & $2.12 \mathrm{E}-01$ & -2 & $2.28 \mathrm{E}-02$ \\
\hline Peonidin-3,5-O- diglucoside & 623.1617 & 0.8 & $4.64 \mathrm{E}-01$ & -2.5 & $2.33 \mathrm{E}-03$ \\
\hline Delphinidin P-Coumaoroyldiglucoside & 678.1614 & 1.1 & $3.01 \mathrm{E}-01$ & -1.67 & $1.37 \mathrm{E}-02$ \\
\hline Panel 4 & & Wet Wild Typ & s Knockout & Dry Wild Typ & vs Knockout \\
\hline \multirow{2}{*}{ Metabolite Name } & \multirow{2}{*}{ IonMZ } & \multicolumn{2}{|c|}{ Col_Wet/Lam_Wet } & \multicolumn{2}{|c|}{ Col_Dry/Lam_Dry } \\
\hline & & Fold Change & P Value & Fold Change & P Value \\
\hline Peonidin-3-O-monoglucoside & 461.1089 & 0.6 & $3.55 \mathrm{E}-02$ & -43.5 & $7.75 \mathrm{E}-05$ \\
\hline Cyanidin-3,5-O-diglucoside & 609.1465 & 13.3 & $7.11 \mathrm{E}-05$ & 4.4 & $1.08 \mathrm{E}-02$ \\
\hline Peonidin-3,5-O- diglucoside & 623.1617 & 2.6 & $5.94 \mathrm{E}-04$ & 1.2 & $5.42 \mathrm{E}-01$ \\
\hline Delphinidin P-Coumaoroyldiglucoside & 678.1614 & 2.2 & $5.12 \mathrm{E}-05$ & 1.2 & $1.96 \mathrm{E}-01$ \\
\hline
\end{tabular}

When specific metabolites were observed to have high fold change differences between the groups, and were compared against the Kegg anthocyanin pathway nodes, we find that the likely nodes of interaction for production of these metabolites would be in the cyanidin and delphinidin nodes (Table 2). 
Table 2. Anthocyanin metabolites and associated genes, location on Kegg Anthocyanin Biosynthesis pathway

\begin{tabular}{|c|c|c|c|c|c|}
\hline Metabolite & Locus & $\begin{array}{l}\text { Kegg Pathway } \\
\text { A. thaliana Gene(s) }\end{array}$ & Function & $\begin{array}{l}\text { Anthocyanin } \\
\text { Node }\end{array}$ & Location \\
\hline $\begin{array}{l}\text { 3-p-coumaroylsinapoylso } \\
\text { phoroside-5-diglucoside }\end{array}$ & $\begin{array}{l}\text { BAA74428, } \\
\text { AT4G14090 }\end{array}$ & AT4 & $\begin{array}{l}\text { anthocyanin-containing compound } \\
\text { biosynthetice procsee, } \\
\text { phenylpropanoid metabolic process }\end{array}$ & Cyanidin & Chloroplasts \\
\hline $\begin{array}{l}\text { 3-caffeoylferuloylsopho } \\
\text { roside-5-succinoylglucoside }\end{array}$ & $\begin{array}{l}\text { BAA74428, } \\
\text { AT4G14090 }\end{array}$ & AT4 & $\begin{array}{l}\text { anthocyanin-containing compound } \\
\text { biosynthetice procsee, } \\
\text { phenylpropanoid metabolic process }\end{array}$ & Cyanidin & Chloroplasts \\
\hline $\begin{array}{l}\text { 3-caffeoylferuloylsopho } \\
\text { roside-5-malonyldiglucoside }\end{array}$ & $\begin{array}{l}\text { BAA74428, } \\
\text { AT4G14090, } \\
\text { AT3G29590 }\end{array}$ & AT4, AT3 & $\begin{array}{l}\text { anthocyanin-containing compound } \\
\text { biosynthetice procsee, } \\
\text { phenylpropanoid metabolic process }\end{array}$ & Cyanidin & Cytoplasm \\
\hline Peonidin-3-O-monoglucoside & AT4G14090 & AT4 & $\begin{array}{l}\text { anthocyanin-containing compound } \\
\text { biosynthetice procsee, } \\
\text { phenylpropanoid metabolic process }\end{array}$ & Cyanidin & Chloroplasts \\
\hline Cyanidin-3,5-O-diglucoside & AT4G14090 & AT4 & $\begin{array}{l}\text { anthocyanin-containing compound } \\
\text { biosynthetice procsee, } \\
\text { phenylpropanoid metabolic process }\end{array}$ & Cyanidin & Chloroplasts \\
\hline Peonidin-3,5-O-diglucoside & AT4G14090 & AT4 & $\begin{array}{l}\text { anthocyanin-containing compound } \\
\text { biosynthetice procsee, } \\
\text { phenylpropanoid metabolic process }\end{array}$ & Cyanidin & Chloroplasts \\
\hline $\begin{array}{l}\text { Delphinidin } \\
\text { p-coumaroyldiglucoside }\end{array}$ & AT4G14090 & AT4 & $\begin{array}{l}\text { anthocyanin-containing compound } \\
\text { biosynthetice procsee, } \\
\text { phenylpropanoid metabolic process }\end{array}$ & Delphindin & Chloroplasts \\
\hline
\end{tabular}

Anthocyanin metabolites such as 3-p-coumaurolysinapoylsophoroside-5-diglucoside and 3-caffeoylferuloy

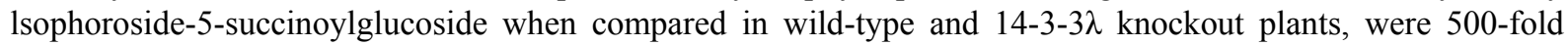

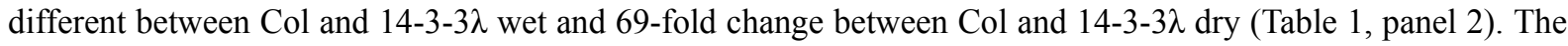

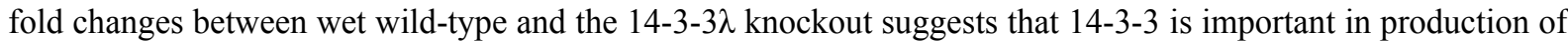
specific anthocyanins such as 3-p-coumaurolysinapoylsophoroside-5-diglucoside, 3-caffeoylferuloylsopho roside-5-succinoylglucoside, 3-caffeoylferuloylsophoroside-5-malonyldiglucoside, 3-feruloylsophoroside-5succinoylglucoside, Petunidin-3,5-O-diglucoside and Malvidin-3-O-p-coumarylmonoglucoside (Table 1, panel 1 to 4). The genes that regulate the metabolites shown in Table 1 are in the synthetic pathway from 4-coumaryl-coA to naringenin chalcone which is then converted to naringenin. These two steps in Pp pathway are regulated by chalcone synthase (CHS) and chalcone isomerase (CHI). Figure 4 represents a heat map distribution of the top 25 anthocyanin metabolites showing that the groups are clustered, demonstrating up or down regulation of the metabolites with consistency amongst the groups and providing confidence in the data which are listed in Table 2. 


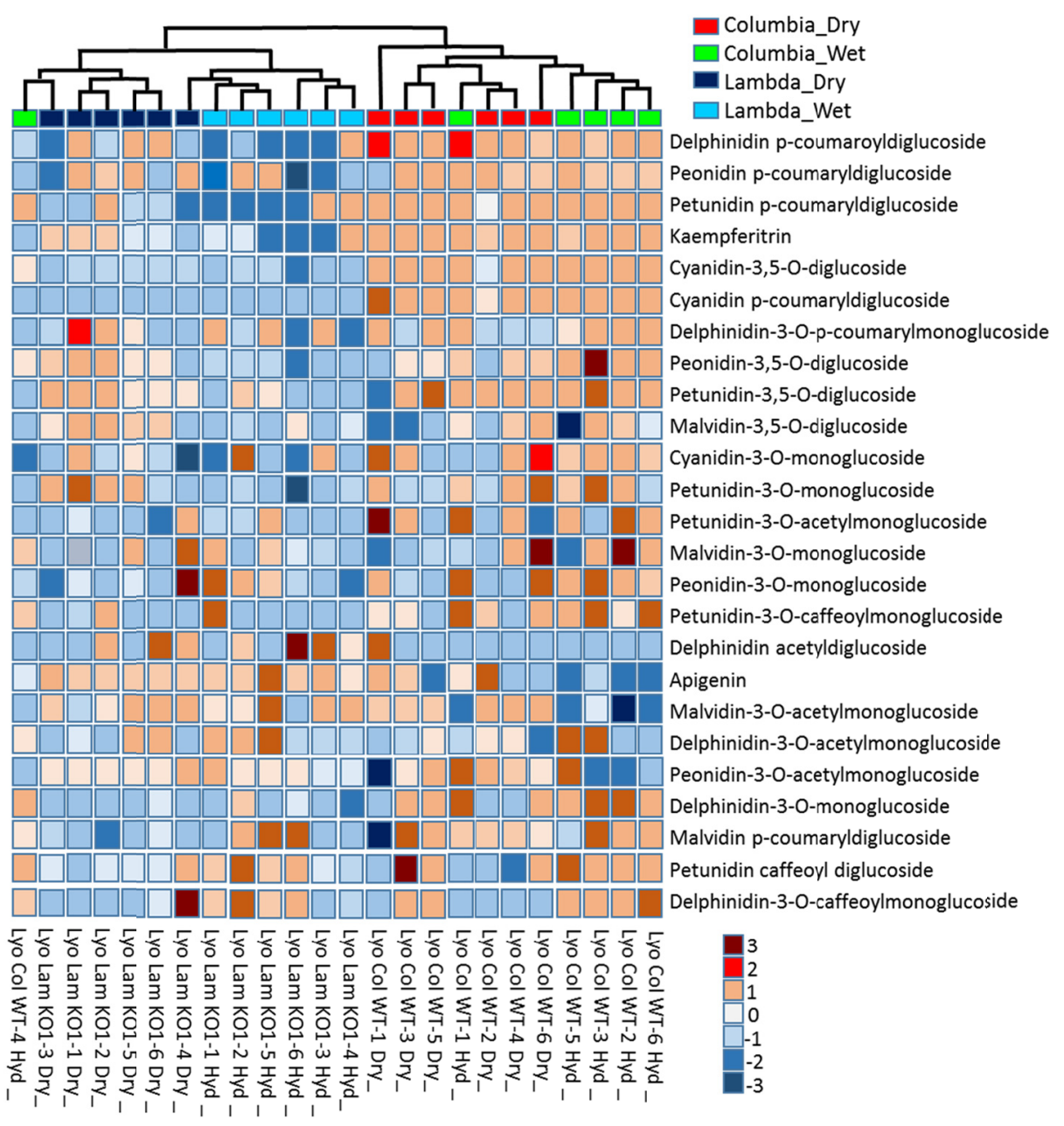

Figure 4. Heat Map for all metabolites analyzed under normal hydration and drought in 14-3-3 $\lambda$ and Columbia. Top 25 metabolites shown (distance measure using euclidean, and clustering algorithm using ward)

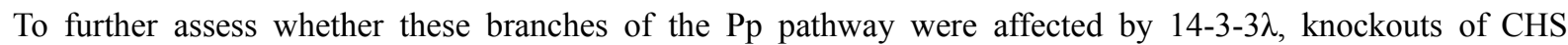
(SALK_077592) and CHI (SALK_034145), which are known to affect anthocyanin production (Huang et al.,

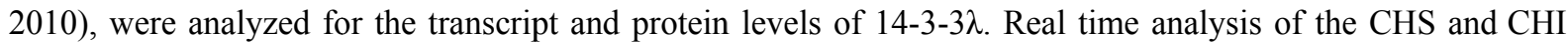

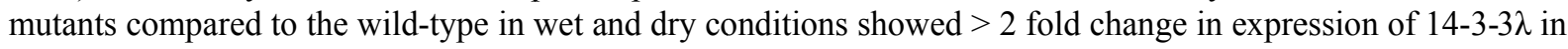
the wet conditions but decreased more than 4 fold under drought conditions (Figure 5). 


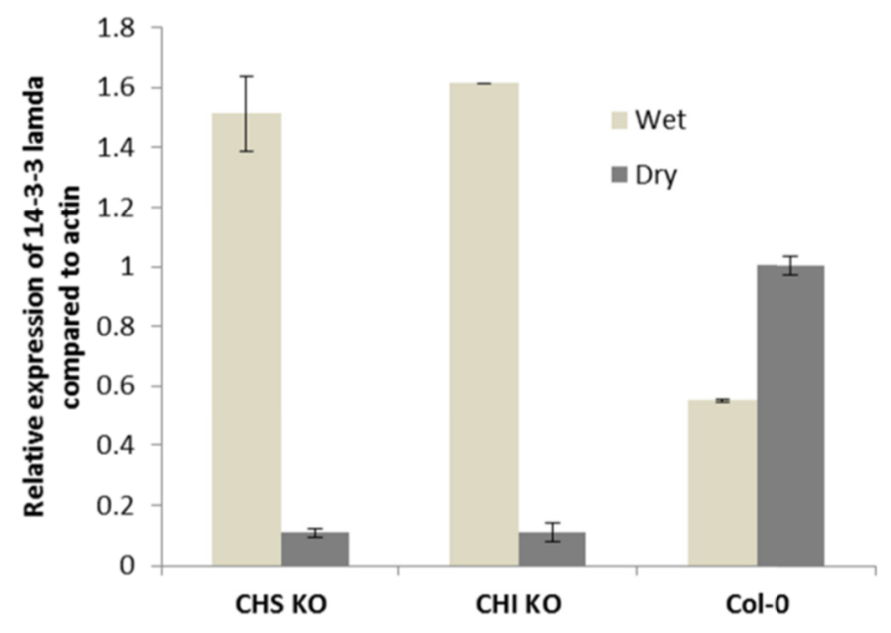

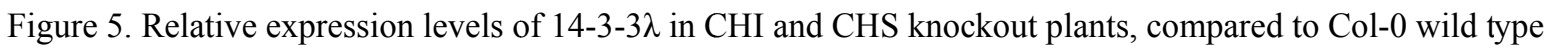
under wet and dry conditions (14-3-3 expression relative to Actin expression)

Western blot analysis of CHS and CHI knockout mutants show a decrease in 14-3-3 $\lambda$ protein under dry

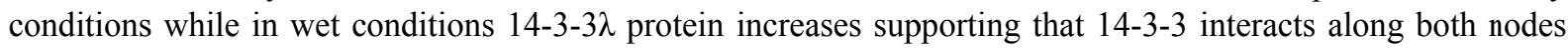
(Figure 6).

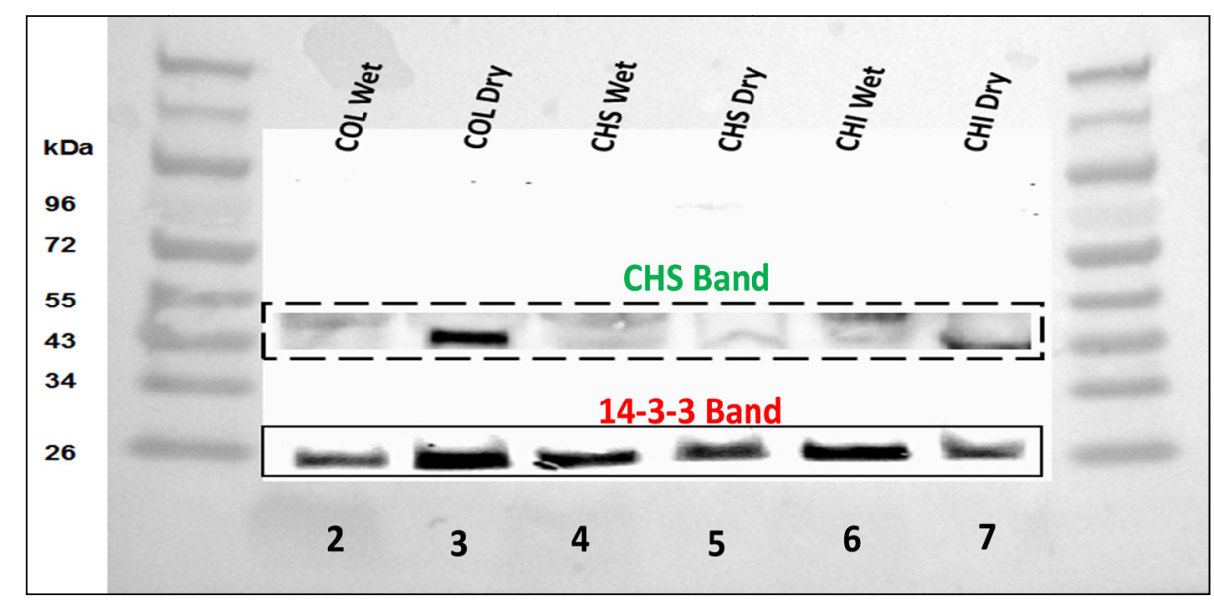

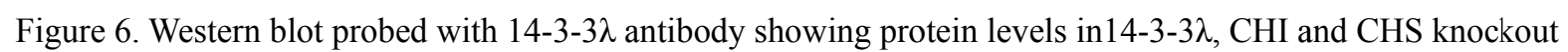
plants, compared to Col- 0 wild type under wet and dry conditions. The 14-3-3 band is shown by the solid line box and the CHS band is shown by the dashed line box

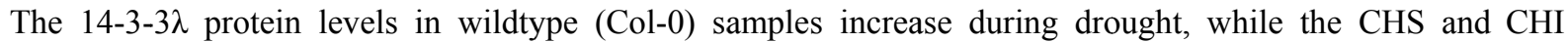
knockout mutants shows no change. This shows that knocking out CHS and CHI affects 14-3-3 expression. Published studies (Chunthaburee et al., 2016; Dao, Linthorst, \& Verpoorte, 2011; Wang et al., 2016) and a review on CHS (Dao et al., 2011), demonstrates that CHS and CHI have increased expression during stress in plants. This suggest that CHS and CHI are likely also increased in expression under drought stress in A. thaliana and supports the observation of differential accumulation of anthocyanins observed in this study.

To investigate if 14-3-3 $\lambda$ and CHS are co-localized during wet and dry conditions, immunolabeling followed by confocal microscopy was carried out on wet and dry Col-0 leaf mass. The image in Figure 7 shows three color images representing a 14-3-3 $\lambda$ specific antibody with fluorescent labeled secondary antibody (red), DAPI stain to see the nucleus (blue) and CHS detection with a secondary antibody (green), were merged into a single image,

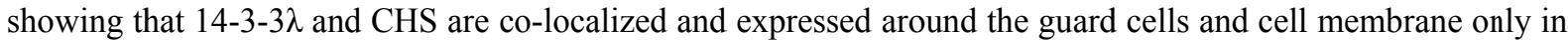
the epidermal cells during wet conditions. The green dots within the cells are CHS in the layer below epidermal 
which is the mesophyll cells. There is no expression of 14-3-3 $\lambda$ in the mesophyll cells and the expression is limited to only the guard cells and the cell membrane in the epidermal cells. The yellow arrow in the merged panel shows line scan analysis of the pixel intensity of the red signal for 14-3-3 $\lambda$ and green signal for CHS. Line scan data is quantified and presented as the fluorescence of each of the three colors in the graph panel at the bottom of the figure. The peaks of each color are right above each other for the spot marked with the yellow arrow representing co-localization of CHS and 14-3-3. Under dry conditions 14-3-3 (red) and CHS (green) signals are similar in intensity and is co-localized in the guard cells and cell membrane.
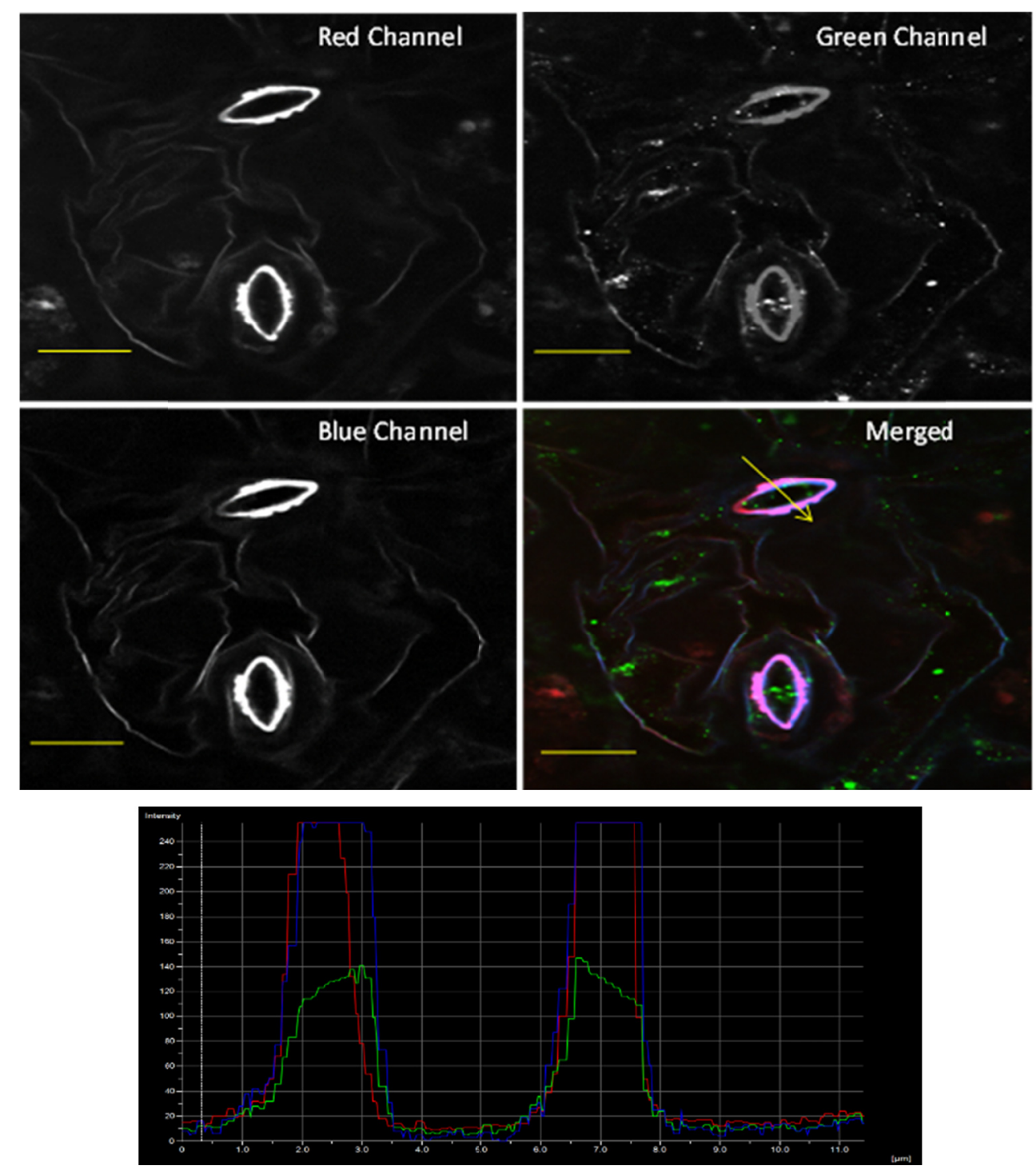

Figure 7. Co-localization analysis of leaf mass from $A$. thaliana under wet conditions. The fluorescence intensity

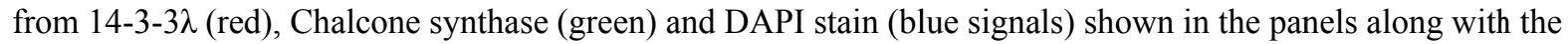
merged image and an intensity graph for the area under the yellow arrow shown in the lower right panel. Yellow scale bar $=10 \mu \mathrm{M}$

The yellow arrow in Figure 8 shows co-localization in guard cell membrane. The bottom graph panel in 8 shows that the green signal intensity is same as red indicating presence of CHS and 14-3-3 $\lambda$ in the same spot. These finding further support the role 14-3-3 $\lambda$ in drought tolerance, as closure of the guard cell is critical to reducing loss of moisture. 

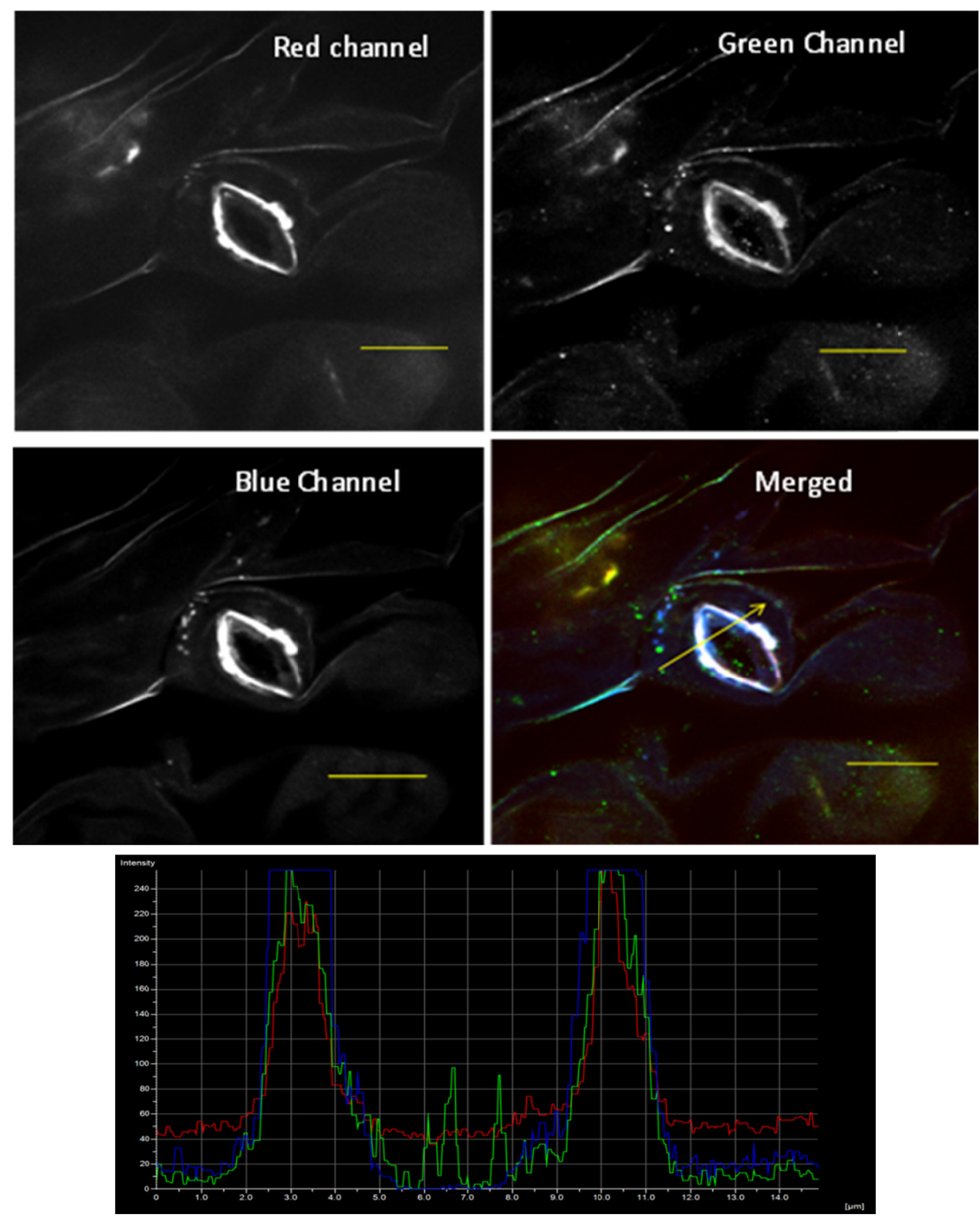

Figure 8. Microscopy analysis of leaf mass from A. thaliana under dry conditions. The fluorescence intensity from red, green, blue signals along with merged image and an intensity graph for the area under the yellow arrow shown in the lower right panel. Yellow scale bar $=10 \mu \mathrm{M}$

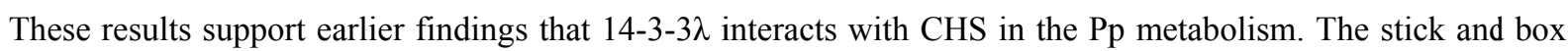
diagram in Figure 9 shows the Pp pathway and highlights the locations along the known pathway where $\mathrm{CHI}$ and CHS enzymes effect production of anthocyanins. 


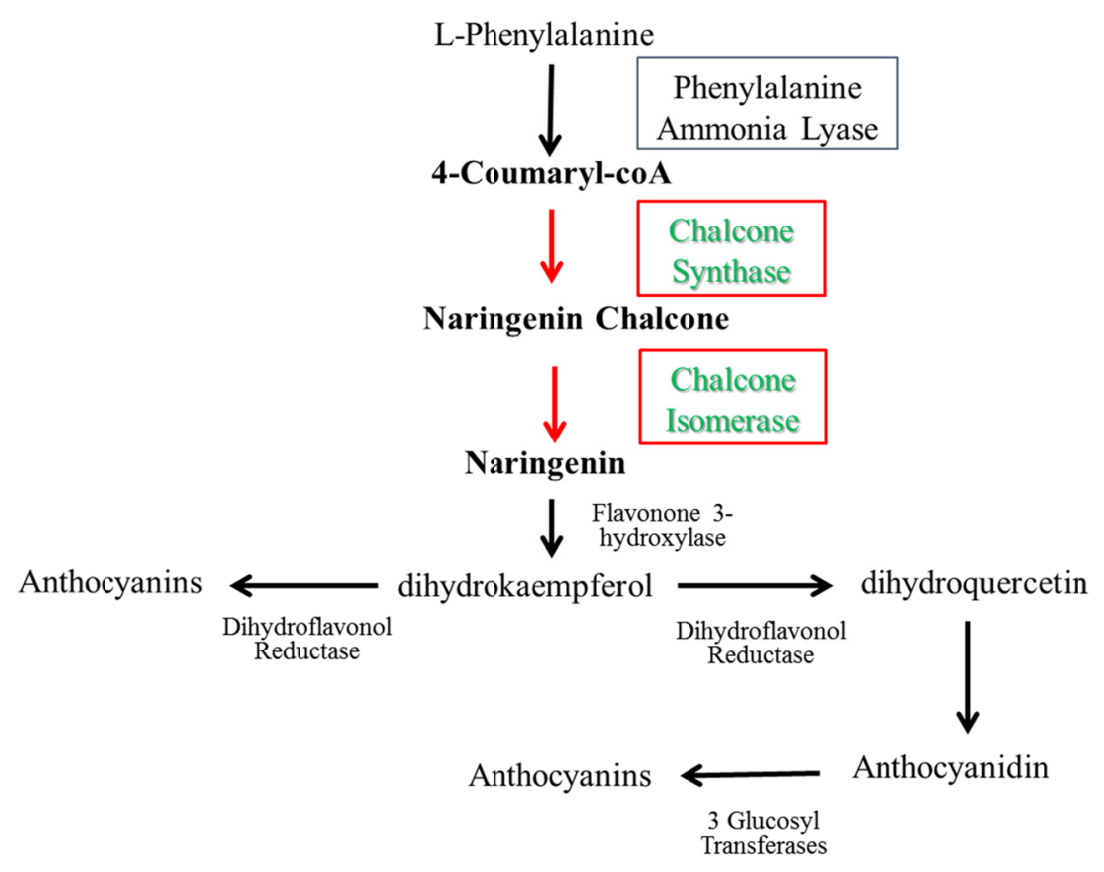

Figure 9. Box and stick pathway for the metabolites with highest fold changes. Knockout plants of CHS and CHI pathway tested under wet and dry conditions to study expression of 14-3-3 under the conditions

Zhao et al., demonstrated that many phospho-peptides, from derived libraries, bind to multiple isoforms of 14-3-3 (Li, Tang, \& Guo, 2016) and the PAL and CHS enzyme can be phosphorylated, which would facilitate

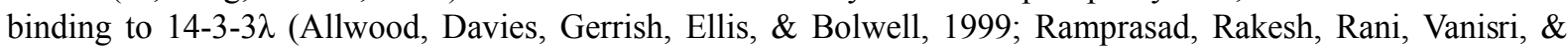
Gajula, 2016). A published study investigating CHS and CHI interaction show that both can bind to each other and co-precipitate, this would suggest that CHI or CHS can be co-precipitates if either is bound to 14-3-3

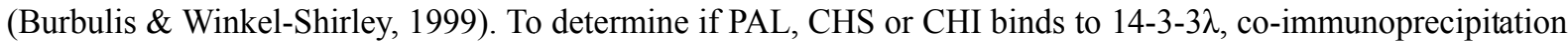

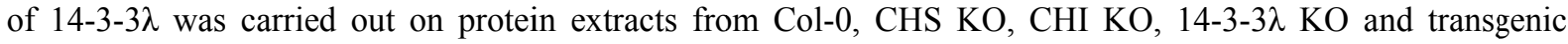

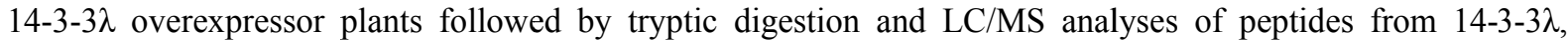
PAL-1, PAL-2, CHS and CHI. Responses were observed for the selected peptides suggesting that these partners were co-precipitated along with 14-3-3 (Table 3). The MS ion current from the 14-3-3 $\lambda$ KO was background subtracted from the ion current for the other samples, then converted to $(+)$ or $(-)$ value based upon presence or absence of a signal for the peptide. The 14-3-3 $\lambda$ overexpressor response was not higher than Col-0 as was expected, but this may be due to extraction differences. For Col-0 and the 14-3-3 $\lambda$ overexpressor, responses were observed for peptides arising from 14-3-3 $\lambda$, PAL-1, PAL-2, CHS, and CHI. Whereas the CHS and CHI knockouts, responses for 14-3-3 $\lambda$, PAL-1 and PAL-2 peptides was seen but no response was seen for CHS and $\mathrm{CHI}$ peptides, since this was expected, it provided additional confidence in the analyses.

Table 3. LC/MS analyses of peptides from Co-immunoprecipitation of 14-3-3 binding partners. Insilico tryptic digestion was used to identify peptides for the analysis. The most abundant peptides were selected for analysis

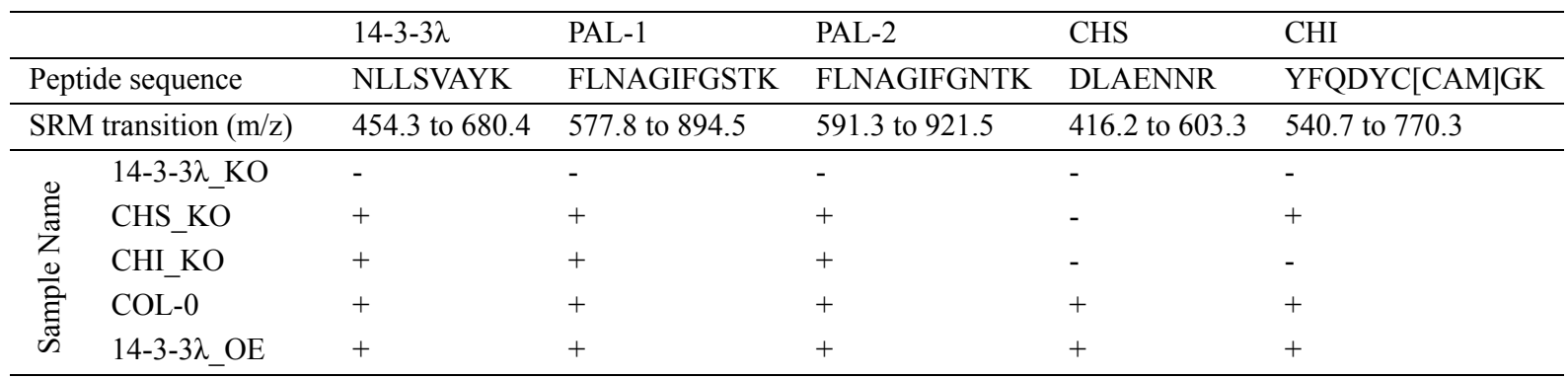

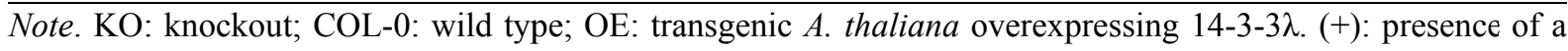
signal for the peptide; (-): absence of a signal for the peptide. 


\section{Conclusion}

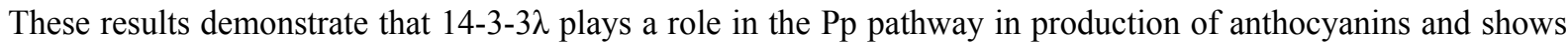

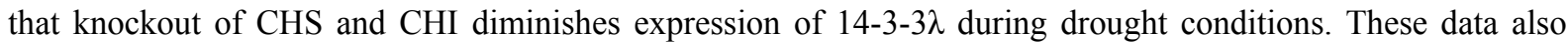
suggest that PAL-1, PAL-2, CHS and CHI are interacting with 14-3-3. These observations demonstrate that knocking out 14-3-3 $\lambda$ results in decreased 14-3-3 expression under drought conditions, consequently resulting in differential accumulation of anthocyanin metabolites in the knocked out line compared to wild-type. Over-expressing 14-3-3 $\lambda$ leads to increased tolerance to drought in these transgenic plants. The plants showed increased accumulation of anthocyanins in the over-expressing transgenic plants providing additional evidence that 14-3-3 is interacting with the chalcone synthase gene and is involved in anthocyanin production. Hence, 14-3-3 $\lambda$ does play an important role in drought tolerance in $A$. thaliana.

\section{References}

Aitken, A. (1996). 14-3-3 and its possible role in co-ordinating multiple signalling pathways. Trends in Cell Biology, 6(9), 341-347. https://doi.org/10.1016/0962-8924(96)10029-5

Allwood, E. G., Davies, D. R., Gerrish, C., Ellis, B. E., \& Bolwell, G. P. (1999). Phosphorylation of phenylalanine ammonia-lyase: Evidence for a novel protein kinase and identification of the phosphorylated residue. FEBS Letters, 457(1), 47-52. https://doi.org/10.1016/S0014-5793(99)00998-9

Berg, D., Holzmann, C., \& Riess, O. (2003). 14-3-3 proteins in the nervous system. Nat Rev Neurosci, 4(9), 752-762. http://dx.doi.org/10.1038/nrn1197

Bihn, E. A., Paul, A.-L., Wang, S. W., Erdos, G. W., \& Ferl, R. J. (1997). Localization of 14-3-3 proteins in the nuclei of arabidopsis and maize. The Plant Journal, 12(6), 1439-1445. https://doi.org/10.1046/ j.1365-313x.1997.12061439.x

Bunney, T. D., van Walraven, H. S., \& de Boer, A. H. (2001). 14-3-3 protein is a regulator of the mitochondrial and chloroplast ATP synthase. Proceedings of the National Academy of Sciences of the United States of America, 98(7), 4249-4254. https://doi.org/10.1073/pnas.061437498

Burbulis, I. E., \& Winkel-Shirley, B. (1999). Interactions among enzymes of the Arabidopsis flavonoid biosynthetic pathway. Proceedings of the National Academy of Sciences of the United States of America, 96(22), 12929-12934. https://doi.org/10.1073/pnas.96.22.12929

Chomczynski, P., \& Sacchi, N. (1987). Single-step method of RNA isolation by acid guanidinium thiocyanate-phenol-chloroform extraction. Analytical Biochemistry, 162(1), 156-159. https://doi.org/ 10.1016/0003-2697(87)90021-2

Chunthaburee, S., Sakuanrungsirikul, S., Wongwarat, T., Sanitchon, J., Pattanagul, W., \& Theerakulpisut, P. (2016). Changes in Anthocyanin Content and Expression of Anthocyanin Synthesis Genes in Seedlings of Black Glutinous Rice in Response to Salt Stress. Asian Journal of Plant Sciences, 15(3-4), 56-65. https://doi.org/10.3923/ajps.2016.56.65

Dao, T. T. H., Linthorst, H. J. M., \& Verpoorte, R. (2011). Chalcone synthase and its functions in plant resistance. Phytochemistry Reviews, 10(3), 397-412. https://doi.org/10.1007/s11101-011-9211-7

DeLille, J. M., Sehnke, P. C., \& Ferl, R. J. (2001). The Arabidopsis 14-3-3 Family of Signaling Regulators. Plant Physiology, 126(1), 35-38. https://doi.org/10.1104/pp.126.1.35

Dixon, R. A., \& Steele, C. L. (1999). Flavonoids and isoflavonoids-A gold mine for metabolic engineering. Trends in Plant Science, 4(10), 394-400. https://doi.org/10.1016/S1360-1385(99)01471-5

Feinbaum, R. L., \& Ausubel, F. M. (1988). Transcriptional regulation of the Arabidopsis thaliana chalcone synthase gene. Molecular and Cellular Biology, 8(5), 1985-1992. https://doi.org/10.1128/mcb.8.5.1985

Ferl, R. J. (1996). 14-3-3 Proteins and Signal Transduction. Annual Review of Plant Physiology and Plant Molecular Biology, 47(1), 49-73. https://doi.org/10.1146/annurev.arplant.47.1.49

Folin, O., \& Denis, W. (1912). TYROSINE IN PROTEINS AS DETERMINED BY A NEW COLORIMETRIC METHOD. Journal of Biological Chemistry, 12(2), 245-251. Retrieved from http://www.jbc.org/content/ 12/2/245.short

He, F., Mu, L., Yan, G.-L., Liang, N.-N., Pan, Q.-H., Wang, J., ... Duan, C.-Q. (2010). Biosynthesis of Anthocyanins and Their Regulation in Colored Grapes. Molecules, 15(12), 9057. https://doi.org/10.3390/ molecules 15129057 
Holton, T. A., \& Cornish, E. C. (1995). Genetics and Biochemistry of Anthocyanin Biosynthesis. The Plant Cell, 7(7), 1071-1083. https://doi.org/10.1105/tpc.7.7.1071

Huang, J., Gu, M., Lai, Z., Fan, B., Shi, K., Zhou, Y.-H., ... Chen, Z. (2010). Functional Analysis of the Arabidopsis PAL Gene Family in Plant Growth, Development, and Response to Environmental Stress. Plant Physiology, 153(4), 1526-1538. https://doi.org/10.1104/pp.110.157370

Ichimura, T., Isobe, T., Okuyama, T., Takahashi, N., Araki, K., Kuwano, R., \& Takahashi, Y. (1988). Molecular cloning of cDNA coding for brain-specific 14-3-3 protein, a protein kinase-dependent activator of tyrosine and tryptophan hydroxylases. Proceedings of the National Academy of Sciences of the United States of America, 85(19), 7084-7088. https://doi.org/10.1073/pnas.85.19.7084

Jahn, T., Fuglsang, A. T., Olsson, A., Brüntrup, I. M., Collinge, D. B., Volkmann, D., ... Larsson, C. (1997). The 14-3-3 protein interacts directly with the C-terminal region of the plant plasma membrane H(+)-ATPase. The Plant Cell, 9(10), 1805-1814. https://doi.org/10.1105/tpc.9.10.1805

Kiranmai, M., Kumar, C. B. M., \& Ibrahim, M. D. (2011). Free Radical Scavenging Activity of Neem Tree (Azadirachta indica A. Juss Var., Meliaceae) Root Bark Extract. Asian Journal of Pharmaceutical and Clinical Research, 4(4), 134-136.

Kumar, K., Muthamilarasan, M., Bonthala, V. S., Roy, R., \& Prasad, M. (2015). Unraveling 14-3-3 Proteins in $\mathrm{C}_{4}$ Panicoids with Emphasis on Model Plant Setaria italica Reveals Phosphorylation-Dependent Subcellular Localization of RS Splicing Factor. PLoS ONE, 10(4), e0123236. https://doi.org/10.1371/journal. pone. 0123236

Lapointe, G., Luckevich, M. D., Cloutier, M., \& Séguin, A. (2001). 14-3-3 gene family in hybrid poplar and its involvement in tree defence against pathogens. Journal of Experimental Botany, 52(359), 1331-1338. https://doi.org/10.1093/jexbot/52.359.1331

Li, R., Jiang, X., Jin, D., Dhaubhadel, S., Bian, S., \& Li, X. (2015). Identification of 14-3-3 Family in Common Bean and Their Response to Abiotic Stress. PLoS ONE, 10(11), e0143280. https://doi.org/10.1371/journal.pone.0143280

Li, S., \& Strid, A. (2005). Anthocyanin accumulation and changes in CHS and PR-5 gene expression in Arabidopsis thaliana after removal of the inflorescence stem (decapitation). Plant Physiology and Biochemistry, 43(6), 521-525. https://doi.org/10.1016/j.plaphy.2005.05.004

Li, Z., Tang, J., \& Guo, F. (2016). Identification of 14-3-3 Proteins Phosphopeptide-Binding Specificity Using an Affinity-Based Computational Approach. PLoS ONE, 11(2), e0147467. https://doi.org/10.1371/ journal.pone. 0147467

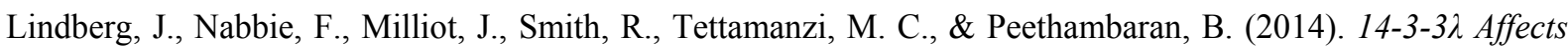
Production of a Sinapoyl Derivative in Lignin Biosynthesis during Drought Stress in Arabidopsis Thaliana.

Lukaszewicz, M., Matysiak-Kata, I., Aksamit, A., Oszmianski, J., \& Szopa, J. (2002). 14-3-3 Protein regulation of the antioxidant capacity of transgenic potato tubers. Plant Science, 163(1), 125-130. https://doi.org/ 10.1016/S0168-9452(02)00081-X

Mahboubi, M., Kazempour, N., \& Boland Nazar, A. R. (2013). Total Phenolic, Total Flavonoids, Antioxidant and Antimicrobial Activities of Scrophularia Striata Boiss Extracts. Jundishapur Journal of Natural Pharmaceutical Products, 8(1), 15-19. https://doi.org/10.17795/jjnpp-7621

Martin, H., Rostas, J., Patel, Y., \& Aitken, A. (1994). Subcellular Localisation of 14-3-3 Isoforms in Rat Brain Using Specific Antibodies. Journal of Neurochemistry, 63(6), 2259-2265. https://doi.org/10.1046/j.1471-4159.1994.63062259.x

Misyura, M., Colasanti, J., \& Rothstein, S. J. (2012). Physiological and genetic analysis of Arabidopsis thaliana anthocyanin biosynthesis mutants under chronic adverse environmental conditions. Journal of Experimental Botany, 64(1), 229-240. https://doi.org/10.1093/jxb/ers328

Moore, B. W. (1967). Specific acidic proteins of the nervous system. Physiological and Biochemical Aspects of Nervous Integratin, 343-359. Retrieved from http://ci.nii.ac.jp/naid/10005184341/en/

Muslin, A. J., \& Xing, H. (2000). 14-3-3 proteins: regulation of subcellular localization by molecular interference. Cellular Signalling, 12 (11 \& 12), 703-709. https://doi.org/10.1016/S0898-6568(00)00131-5 
Pasternak, T., Tietz, O., Rapp, K., Begheldo, M., Nitschke, R., Ruperti, B., \& Palme, K. (2015). Protocol: An improved and universal procedure for whole-mount immunolocalization in plants. Plant Methods, 11(1), 50. https://doi.org/10.1186/s13007-015-0094-2

Paul, A.-L., Denison, F. C., Schultz, E. R., Zupanska, A. K., \& Ferl, R. J. (2012). 14-3-3 phosphoprotein interaction networks-Does isoform diversity present functional interaction specification? Frontiers in Plant Science, 3, 190. https://doi.org/10.3389/fpls.2012.00190

Peethambaran, B., Chi Li, T., Dzugan, P., Xiang, W., \& Balsamo, R. (2012). Physiological and Mechanical Role of 14-3-3 Lambda in Arabidopsis thaliana during Drought Stress. Journal of Agricultrual Science, 4(8), 149-163. https://doi.org/10.5539/ jas.v4n8p149

Ramprasad, E., Rakesh, G., Rani, C. V. D., Vanisri, S., \& Gajula, M. P. (2016). In silico analysis of chalcone synthase 1 protein sequences from different plant species. International Journal of Science, Environment and Technology, 5(4), 1968-1979.

Roberts, M. R. (2003). 14-3-3 Proteins find new partners in plant cell signalling. Trends in Plant Science, 8(5), 218-223. https://doi.org/10.1016/S1360-1385(03)00056-6

Roberts, M. R., Salinas, J., \& Collinge, D. B. (2002). 14-3-3 proteins and the response to abiotic and biotic stress. Plant Molecular Biology, 50(6), 1031-1039. https://oi.org/10.1023/A:1021261614491

Rosenquist, M., Sehnke, P., Ferl, R. J., Sommarin, M., \& Larsson, C. (2000). Evolution of the 14-3-3 protein family: does the large number of isoforms in multicellular organisms reflect functional specificity? $J$ Mol Evol, 51(5), 446-458. https://doi.org/10.1007/s002390010107

Wang, W., Xin, H., Wang, M., Ma, Q., Wang, L., Kaleri, N. A., ... Li, X. (2016). Transcriptomic Analysis Reveals the Molecular Mechanisms of Drought-Stress-Induced Decreases in Camellia sinensis Leaf Quality. Frontiers in Plant Science, 7(795), 385. https://doi.org/10.3389/fpls.2016.00385

Xia, J., Sinelnikov, I. V., Han, B., \& Wishart, D. S. (2015). MetaboAnalyst 3.0-Making metabolomics more meaningful. Nucleic Acids Research, 43(W1), W251. https://doi.org/10.1093/nar/gkv380

\section{Copyrights}

Copyright for this article is retained by the author(s), with first publication rights granted to the journal.

This is an open-access article distributed under the terms and conditions of the Creative Commons Attribution license (http://creativecommons.org/licenses/by/4.0/). 